RESEARCH ARTICLE

\title{
Classical Nature: Natural History, Classical Humanism, and the Value of Knowledge in Sweden, 1800-1850
}

\author{
Isak Hammar \\ Stockholm University, SE \\ isak.hammar@historia.su.se
}

\begin{abstract}
This article investigates a series of attempts to imbue natural history with humanistic values and align its epistemological goals with those of classical studies in Sweden during the first half of the nineteenth century. By tracing the claims made by a group of twenty-one natural scientists, physicians, and state officials as well as others who took up the cause in response to a government proposal for a new school ordinance, this paper demonstrates how natural history became linked to self-cultivation and edification (Bildung, or bildning in Swedish) while the material and practical utility it was once so strongly associated with was downplayed in favor of moral development. It argues that a knowledge regime favoring the humanities in general and classical studies in particular strongly influenced secondary education, leading the group to claim that the study of nature should be treated as part of classical education. Although their argumentation subordinated the natural sciences to the humanities, they and later advocates accepted the new knowledge regime as they were themselves part of an academic culture of classical humanism. The key role that natural history played in this struggle over the educational and social value of different forms of knowledge during this period demonstrates that the history of science can be enriched by including the historical impact of the humanities on the natural sciences.
\end{abstract}

Keywords: history of humanities; history of knowledge; natural history; classical education; "two cultures"

In December 1818, a group of twenty-one natural scientists, physicians, and state officials in Sweden sent their collectively written pamphlet, Anmärkningar om natural-historiens lärande vid rikets lägre läroverk (Remarks on the teaching of natural history in the kingdom's lower grammar schools), to the Swedish government's Education Committee outlining their objections to a proposal for reforming secondary education it had circulated the previous year. ${ }^{1}$ In keeping with developments in Europe, the Committee's Proposal for an Improved School Ordinance (Förslag till en förbättrad skol-ordning), later formalized as the Swedish School Ordinance of 1820, put a strong emphasis on Latin and classical literature in the curriculum for gymnasia to ensure the harmonious progression of the student's mental faculties and moral sensibilities. The focus on self-cultivation or Bildung (bildning in Swedish) left little room for natural history or other fields of natural science. ${ }^{2}$ The signees of the Anmärkningar were deeply concerned about the diminished state of the natural sciences in Sweden and were intent on restoring some of their former glory by focusing on the value of natural history in secondary education. The pedagogical and scientific legitimacy of the natural sciences had come under scrutiny in the early nineteenth century because of their association with economic gain. Instead of disputing the proposal's classical humanist emphasis, however, the signees argued that natural history and the natural sciences more generally conferred the same pedagogical benefits on the student-

\footnotetext{
${ }^{1}$ Trafvenfelt, Anmärkningar.

2 On the hegemony of classical education in this period, see Phillips, Acolytes; Bommel, Classical Humanism; Nilehn, Nyhumanism; Hammar, "Conflict among Geniuses."
} 
intellectual and moral development-as a classical humanist education and downplayed the practical or economic benefits they were so strongly associated with. ${ }^{3}$ They even went so far as to claim that natural history should be considered a "classical" subject. ${ }^{4}$

The Education Committee ultimately paid little heed to the objections the group raised and endorsed classical humanism as the most suitable form of education for secondary schools. It would be another three decades before natural history and the natural sciences as a whole would acquire a significant place in the curriculum. Nevertheless, the remonstrances the group laid out in the Anmärkningar expose the material and symbolic disadvantages natural scientists in Sweden and in Europe more broadly felt at the time. ${ }^{5}$ In this paper, I argue that the future of the natural sciences in Sweden became closely tied to the success of endeavors to redefine natural history after the standard set by classical humanism. ${ }^{6}$ In what follows, I trace the attempts by members of the group as well as others to position natural history as humaniora, that is, as belonging within the sphere of the humanities as contemporaries variously defined it and to align its epistemological goals with classical studies, the most hegemonic form of the humanities at the time.

To do so, I focus on the negotiations that ensued in Sweden from 1818 to the early 1850s over what constituted socially valuable knowledge with the aim of connecting the specific goals of those who advocated for the natural sciences in general and natural history in particular to a larger shift in the epistemological hierarchy that favored the humanities. ${ }^{7}$ While the ongoing efforts to include natural history in the sphere of classical humanism were never fully accepted and can thus be seen as part of a failed strategy, they are nevertheless valuable as a prism through which to view the wider cultural conflict between different forms of knowledge during this period. ${ }^{8}$ As this paper will show, the Anmärkningar was not the only document championing the humanistic value of natural history and the natural sciences more generally that was circulating in the Scandinavian public sphere between 1800 and $1850 .{ }^{9}$ But changes in the organization of Swedish secondary schools in the early 1850 s did much to alleviate the pressure created by the cultural ascendance of classical humanism at the turn of the century. Before this shift, however, the issues raised by the Anmärkningar preoccupied some of Sweden's and Scandinavia's most prolific scholars as well as their lesser known contemporaries for at least half a century at a time when the threat to the natural sciences was arguably at its most dire historically.

The paper begins with the attempts of the signees of the Anmärkningar to reframe the pedagogical and cultural value of natural history in a way that aligned it more closely with classical humanism. The Anmärkningar provides an unusually rich source for outlining their endeavors in detail. As a rare joint effort written by a group with a common cause entangled in the issue of how to value science and knowledge, it offers considerable insight into the negotiations that spanned the first half of the nineteenth century in Sweden and in Scandinavia more broadly. The challenges that natural scientists faced during this period are visible on its pages, as is the humanities-centered knowledge regime, a regime that advocates for natural history tried to appropriate or circumvent.

\section{A Tale of Two Cultures?}

What was really at stake in these debates? Why the demonstration of unity by such a diverse group of actors and why at this particular point in time? To answer these questions, we must begin with a shift at the end of the eighteenth century in how the value and utility of knowledge acquired through the study of the humanities on the one hand and the natural sciences on the other was perceived in Sweden and elsewhere in Europe. ${ }^{10}$ As Karin Johannisson has argued, the notion of what was considered a public good (nytta) underwent a transformation during this period from a social benefit attained through economic and material progress to one attained through the moral improvement of society and its citizens. ${ }^{11}$ This shift

\footnotetext{
${ }^{3}$ On classical education in Europe, see Stray, Classics Transformed, 83-113; Waquet, Latin; Leonhardt, Latin.

${ }^{4}$ Trafvenfelt, Anmärkningar, 24.

5 See Torstendahl, "Transformation." In general, see also Eriksson, "Motiveringar"; Eriksson, I andans kraft, 283-326.

${ }^{6}$ See Veit-Brause, "Scientists," 38-39.

7 On epistemological hierarchy, see Daston, "Comment," 176; "History of Knowledge," 145. See also Jacob, "Lieux de savoir," 86. Cf. Krämer, "Shifting Demarcations," 11.

${ }^{8}$ On natural history in Sweden, see Beckman, "Nature's Palace"; "Collecting Standards." In general, see Spary, Utopia's Garden; Ogilvie, Science of Describing; Jardine et al., Cultures of Natural History, and also Curry et al., Worlds of Natural History.

${ }^{9}$ For an international comparison, see Bommel, Classical Humanism, 147-51; Daum, Wissenschaftspopularisierung, 52-57; and Phillips, Acolytes, 228-36. See also Leonhardt, Latin, 275-76.

${ }^{10}$ See, e.g., Clark, Academic Charisma, 443-49; Fuchs, "Nature and Bildung," 155-81; Daum, "Science, Politics, and Religion," 107-40, $112-13$.

${ }^{11}$ Johannisson, "Naturvetenskap på reträtt," 129-30. See also Liedman, "Utilitarianism and the Economy," 23-44.
} 
proved detrimental to the standing of the natural sciences because of their close association with practical knowledge and economic gain. Conversely, it rendered the humanities, especially classical studies, the normative form of knowledge, at once reflecting society's expectations of higher education and establishing it as the model for the natural sciences. ${ }^{12}$ During the same period, classicists in Sweden and elsewhere in Europe found a new raison d'être in the theory of formale Bildung, which dictated that the goal of education, particularly in gymnasia, was not to furnish vocational or practical knowledge but to train the mental faculties and cultivate the mind. Formale Bildung became the governing philosophical idea underlying the harmonious development of an individual into a moral and productive citizen, and its adoption as a pedagogical goal made the classical languages the premier tool for achieving this goal. ${ }^{13}$ These changes in turn shifted the meaning of the term vetenskaplig, which, like the German "wissenschaftlich," referred to all fields of academic study including the natural sciences and the humanities, in a direction that favored the humanities and that was further removed from practical knowledge for material gain. ${ }^{14}$ This change in pedagogical ideals, as Eckhardt Fuchs has pointed out, led to the "discursive and institutional hegemony" of the humanities that was upheld by philosophers as well as school officials and teachers. ${ }^{15}$

The impact of this shift in the kind of knowledge considered socially valuable in secondary education reform reached a critical point in 1818 when the group sent their Anmärkningar to the Education Committee. ${ }^{16}$ Attempts to reform secondary education became a constant feature of Swedish political and public discourse following a new school ordinance instituted in $1807 .^{17}$ Complicating matters, Sweden adopted a new constitution in 1809 after the loss of Finland to Russia and the abdication of the Swedish king. Thereafter, the issue of reforming secondary education became riven with political strife and uncertainty, fueled by an expanding public sphere. Calls for more inclusive and practically oriented education were shaped by new ideas of citizenship, patriotism, and equality. Yet, despite the ongoing attempts to reform secondary education in Sweden, the strong orientation of the curriculum towards classical humanities remained firmly in place, leaving the natural sciences in an unfavorable position. By 1832, the position of the humanities was so entrenched that in yet another round of negotiations with yet another government committee tasked with educational reform, advocates for the natural sciences simply submitted the Anmärkningar unaltered in a further attempt to gain some ground on the curriculum. It was not until a parallel school program devoted to modern languages, mathematics, and the natural sciences was introduced in the middle of the century that a more equal balance between a classical and a practical, scientifically oriented education became possible. ${ }^{18}$

The writing of the Anmärkningar and the logic behind its argumentation thus must be viewed against a backdrop of the decline in the status of the natural sciences and the ascendance of the humanities at the turn of the nineteenth century. Although both categories were nebulous at the time, they were regularly employed..$^{19}$ Sources from this period contain numerous terms to denote the larger field of the natural sciences, including the most literal, "naturvettenskaper," introduced by Carl Linnaeus in 1763. Similarly, the field of knowledge subsumed under the humanities was referred to by different terms, including "humaniora" and "humanistisk vetenskap" (literally, humanistic science), which sometimes referred only to classical studies proper. ${ }^{20}$ In both cases, the categories were imprecise and the nomenclature was anything but stable. Moreover, in the former case, the problem was complicated by the fact that the terms used for natural history and the natural sciences often overlapped in scientific discourse as well as in the Anmärkningar itself.

In recent years the relationship between the natural sciences and the humanities has begun to be reevaluated. Scholars, particularly those in the new field of the history of the humanities, are now actively

\footnotetext{
${ }^{12}$ Kutschmann, Naturwissenschaft und Bildung, 73. See also Bouterse and Karstens, "Diversity," 346; Daum, "Science, Politics, and Religion," 113; Yeo, Defining Science, 32-33.

13 On formale Bildung, see Bommel, Classical Humanism, 115-33. Cf. Leonhardt, Latin, 263-69; and Hamann, "Bildung," 53-54. For the circulation of formale Bildung in Sweden, see Hammar, "Conflict, Consensus, and Circulation."

${ }^{14}$ Bommel, "'Bildung' und 'Wissenschaft,"” 10-11, 24-25. Cf. Daston, "History of Science," 384, 387.

15 Fuchs, "Nature and Bildung," 155.

${ }^{16}$ The Committee received 39 responses to its 1817 proposal, but few touched upon natural science. See Askeberg, Pedagogisk reformverksamhet, 117.

${ }^{17}$ Standard works on this topic include Wennås, Striden om latinväldet; Segerstedt, Akademiska friheten; Florin and Johansson, Härliga lagrarna.

${ }^{18}$ Eriksson, I andans kraft, 111-14; Kärnfelt, Mellan nytta och nöje, 156; Löwegren, Naturaliesamlingar, 25; Beckman, "Collecting Standards," 241

19 See Blair, "Disciplinary Distinctions," 577-78.

${ }^{20}$ Today, humaniora denotes the field of the humanities in Sweden, although humanvetenskaper, or literally, the human sciences, is sometimes used interchangeably.
} 
examining the impact the humanities has had on the development of the natural sciences and vice versa, "working toward one common, integrated history" of the two. ${ }^{21}$ It is now widely held that there was a considerable degree of transfer of both knowledge and practices between these fields. ${ }^{22}$ According to HansJörg Rheinberger, the encounter between the two should be treated as "part of the basic toolkit" for the history of science. ${ }^{23}$

The public negotiations over the value of knowledge that the group took part in by publishing the Anmärkningar reveals the imbalance in Europe at the time between what later came to be categorized as the "two cultures." ${ }^{24}$ The term "two cultures," as Guy Ortolano has shown, can obscure more than it reveals. Yet it remains tempting to invoke it as a means of bringing the relationship between the natural sciences and the humanities together in a wider analytical frame. ${ }^{25}$ As Julian Hamann has suggested, while the "two cultures" did not exist at the beginning of the nineteenth century in the sense of being the "systematic schism" and "discursive distinction" found towards its end, focusing on the boundaries preceding the emergence of a visible division between the two allows for an analysis of the "symbolic strategies that define[d] legitimate scientific activity" in their historical context. ${ }^{26}$

Whether two distinct cultures existed or not, frustrations over the imbalance between the natural sciences and classical humanism are readily apparent in Swedish sources from the period. For example, the renowned chemist Jöns Jacob Berzelius, one of the most stalwart defenders of the natural sciences at the time, complained that any effort to include them in the curriculum was regarded by critics as an outright attempt to "totally obliterate" classical learning (den klassiska lärdomen) ${ }^{27}$ Similarly, the well-known botanist Elias Fries denied that such a staunch demarcation existed between the two, arguing that upholding what he called a "caste differentiation" between them was harmful to both "humanistic sciences" (humanistiska vettenskaperna) and the "natural sciences" (Naturvettenskaperna). ${ }^{28}$ Others agreed that the incongruity between the two spheres of knowledge was exaggerated and tried to align them. In an article published in the scientific journal Skandia in 1837, the botanist Johan Petter Arrhenius claimed-with an overt reference to the Anmärkningar-that natural history was not "an opposing science" to any of the "knowledge forms of the humanities" (humanistiska kunnskapsarterne). On the contrary, to its very core natural history displayed a "kinship" with these forms of knowledge and should be regarded as a means of fostering "humanistic selfcultivation" (humanistisk bildning) ${ }^{29}$ Thus, although the terminology was shifting, imprecise, and constantly negotiated, ideas of division and conflict as well as alignment and consensus informed the debates about their respective places in the secondary school curriculum.

\section{A Higher Purpose for the Study of Nature}

That the natural sciences were not yet the exclusive domain of professional academics is evident in the fact that the signees of the Anmärkningar heralded from a diverse range of occupations, such as positions in the civil service and practical medicine, as well as from the Swedish nobility-although some, including Carl Peter Thunberg, were university professors. ${ }^{30}$ Most of them, however, were members of the Royal Swedish Academy of Science. What united the group, which was most likely led by the physician Eric Carl Trafvenfelt, was the belief that natural history constituted a legitimate and valuable scientific and pedagogical endeavor as well as a form of knowledge that was fundamental to the future of the Swedish state. While natural history had been added to the curriculum of Swedish schools and gymnasia in 1807, it was allocated only one hour per week. ${ }^{31}$ Although the number of allotted hours was increased slightly a decade later, economic resources remained so scarce that in reality natural history was given very little consideration. Hence, among the many demands of the fifty-page Anmärkningar was an increase in the number of hours given to natural history in the gymnasium curriculum as well as the hiring of expert teachers.

\footnotetext{
${ }^{21}$ Bod and Kursell, "Introduction," 338.

22 Bod et al., "New Field," 1-2; Bod and Kursell, "Introduction," 337. For the overlap between the humanities and the sciences, see Bod et al., "Introduction," 14; Bod, "Comparative Framework," 368. See also Bouterse and Karstens, "Diversity of Divisions," 341, 352.

${ }^{23}$ Rheinberger, "Culture and Nature," 178.

24 Snow, Two Cultures. Cf. Krämer, "Shifting Demarcations"; Bod, "Divide?"

${ }^{25}$ Ortolano, Two Cultures, 4. Cf. Cunningham and Williams, "Big Picture," 407; Blair, "Disciplinary Distinctions," 582.

${ }^{26}$ Hamann, "Boundary Work," 27-29. Bouterse and Karstens, "A Diversity," 341, 346.

27 Berzelius, Själfbiografiska anteckningar, 92.

${ }^{28}$ Fries, Inträdes-tal, 6.

${ }^{29}$ Arrhenius, "Om Natural-historien," 131. For similiar viewpoints, see Siljeström, "Om naturvetenskapernas studium"; Bergius, "Är tiden."

30 See Kärnfelt, Mellan nytta och nöje, 107-12. See also Siraisi, History, 261-68.

${ }^{31}$ For the situation in German gymnasia, see Daum, Wissenschaftspopularisierung, 45-46; for France, see Waquet, Latin, 7-19.
} 
Deliberations over secondary school reform were directly linked to establishing the role of the natural sciences in society at large. ${ }^{32}$ Publishing the Anmärkningar as a pamphlet demonstrated that the group had a broader audience in mind and that their ambition was to raise the status of the natural sciences in Sweden by responding methodically to the objections raised over their inclusion in the curriculum as well as doubts about their social value that had been voiced frequently in the public sphere. ${ }^{33}$ As Denise Phillips has pointed out, the often heated debates about secondary school curricula are crucial for understanding the wider issue of the division between the natural sciences and the humanities. ${ }^{34}$ The self-cultivation (or Bildung) that was so strongly associated with the humanities was intended to produce useful civil servants with a strong moral character, something that the practical orientation of the sciences was not believed capable of-in fact, it was widely considered to impede it. ${ }^{35}$ Thus, as long as the natural sciences were equated with practical goals, they would be kept out of secondary schools, which not only hindered scientific training at universities but also confirmed their uselessness to society.

To justify raising the status of the natural sciences, then, their value needed to be established within a knowledge regime that strongly favored the humanities and classical studies. Thus, in a bid to align their aims with societal expectations, the group set out to construe natural knowledge as a form of classical knowledge, professing that:

[W] hen Nature is accurately perceived, knowledge of it becomes classical, as a necessary instrument to cultivate humanity, and the natural sciences unconditionally demand their place among our subjects, in order to contribute to our complete human education. ${ }^{36}$

The group also proposed that the basics of natural history ought to be counted as part of "a better or so-called classical upbringing." ${ }^{37}$

What, then, did it take for such an alignment to be successful? What were the characteristics of classical studies that needed to be emulated or matched? Raising the status of natural history meant shedding its instrumental, practical form and assigning it a deeper meaning spiritually and morally. Natural inquiry had to become something else than the patient and painstaking recording of nature if it was to count as a legitimate form of state-sponsored knowledge. To this end, the Anmärkningar began by pointing out that natural history's "higher purpose" was the cultivation of "true humanity." 38 This in turn meant that possessing a knowledge of nature became inseparable from "the cultivated individual." 39

The supremacy of classical education in Europe was based on two tenets: (1) Latin was the best tool for training the mind; and (2) the study of the classical world fostered a citizenry with moral character. Consequently, if those defending natural history wanted it to enjoy the status of being "classical," they would have to find a way of convincing others that it too could serve as an instrument for fostering the harmonious mental development of the student. This, however, proved to be anything but an easy task. The Education Committee had maintained that natural history was too vast a field and thus not capable of providing the logical focus necessary to hone the mind of the student and that its study would take valuable time away from other fields that were "truly cultivating." 40 The popularity of such a view stymied politicians who sought to have more of the natural sciences taught in secondary schools. For example, when Count Carl Henric Posse lamented the disregard for natural history, chemistry, and mechanics in the secondary school curriculum before the Swedish House of Nobility in 1823, he was met with the well-worn maxim that knowledge of Latin prepared students for any and all professions as well as academic and scientific enterprises. $^{41}$

Still, the notion that natural history could fulfill many of the same goals as classical studies was not uncommon among natural scientists in Sweden or in Scandinavia more broadly. As early as 1799, the Danish educator Jacob Saxtorph had singled out natural history as the best method for training the "the

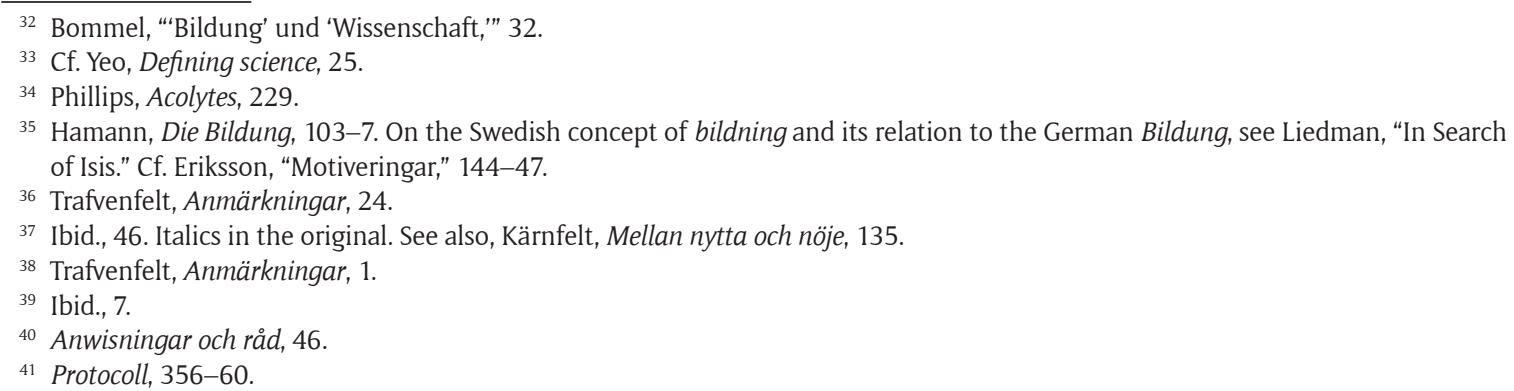


senses and the memory" (Sandserne og Hukommelsen). ${ }^{42}$ When the first Danish polytechnic institute was commemorated in 1829, the superintendent physicist and chemist Hans Christian Ørsted emphasized the value of the natural sciences for the "progression of the soul," not least for individuals involved in mercantilist enterprises ${ }^{43}$ In a letter written in 1836 to Berzelius, his close friend and confidant, Ørsted expressed his belief that their study was a suitable instrument for formal education, the goal of which was to train the mental faculties, referred to in Sweden as själsförmögenheterna, "the faculties of the soul," which included memory, wit, imagination, rationality, and self-dependence. ${ }^{44}$

The Humboldtian ideal of wissenschaftliche Bildung (scientific education) played a key role in developing the idea that the natural sciences could claim the same educational value as the humanities. ${ }^{45}$ In the Anmärkningar, the group made this its first order of business, arguing that natural history ought to be seen as an instrument for building personal character (bildningsmedel, cf. the German Bildungsmittel) and that the methodical study of nature was not only useful but necessary for the awakening and development of the soul at a young age. ${ }^{46}$ Quoting the section of the Education Committee's proposal stating the curriculum should be focused on subjects that occasioned a "progressive development of the faculties of the soul," the group claimed that natural history involved precisely this kind of training-even more so than other subjects-and should be introduced at a young age when the student's mind was still open. ${ }^{47}$ Hence, the study of nature could be just as valuable as "languages, history and the so-called Humaniora." ${ }^{\text {" }}$ Such claims were emblematic of how the issue was debated, with usefulness and self-cultivation-which often appeared in tandem in public and academic discourses -as the central principles underlining the group's quest for recognition. ${ }^{49}$

Yet the claim that natural history was useful to society as well as furnished a means of fostering Bildung was fiercely opposed by some factions in both Sweden and neighboring Scandinavian countries. ${ }^{50}$ For example, in the 1830s both Joachim Frederik Schouw, professor of botany at Copenhagen University, and Anton Martin Schweigaard, a politician and professor of legal theory and economics at the University of Christiana (now Oslo), met with intense resistance when they promoted natural history as an instrument for cultivating the mind. ${ }^{51}$

However, to achieve an amalgamation between the natural sciences and the classically oriented humanities, it was not enough to sharpen the mind. Character formation was just as essential, prompting advocates of natural history to imbue the subject with moral qualities and the capacity of "ennobling" students to safeguard them against vice. ${ }^{52}$ Previous generations of Swedish natural scientists had faced no such need to justify their field. In the so-called Age of Liberty (1718-1772), when the Swedish monarchy was replaced by a parliamentary government, the natural sciences had been at the peak of their societal standing, enjoying an important position in mercantilist ideology and related visions of building a better society. ${ }^{53}$ In this more friendly climate, for example, the first chair in natural history at Lund University (established in 1756) had been sponsored by a national fund for manufacture. Furthermore, its first occupant, Erik Gustaf Lidbeck, had been a proponent of the practical-economic value of the natural sciences. But by 1811, Lidbeck's successor, Anders Jahan Retzius, was forced to associate the field with benefits other than economic ones. In a tract published with the explicit purpose of defending natural history, Retzius emphasized the links between the study of nature and the awakening of religious feelings in students. ${ }^{54}$ This sentiment was echoed in the Anmärkningar: the group maintained that the study of natural history instilled a love of the "Supreme Being" and that there were no natural scientists who were atheists, claiming instead that many, including their great predecessor Linnaeus, had found "a living divine force" in the study of nature. ${ }^{55}$ Samuel Ödmann,

\footnotetext{
42 Saxtorph, Forsøg til en Larebog, 3-4.

43 Ørsted, "Virkning," 66-67. See also Ørsted, "Naturvidenskaben."

44 Ørsted to Berzelius, 23 March 1835, 30.

45 See Bommel, “'Bildung' und 'Wissenschaft,'” 25-26. See also Phillips, Acolytes, 230.

46 Trafvenfelt, Anmärkningar, 1.

47 Ibid., 38-39.

48 Ibid., 34

49 See, e.g., Clark, Academic Charisma, 446-47; Veit-Brause, "Scientists," 38; Phillips, "Friends of Nature," 55.

50 See, e.g., Hjort, Tanker, 45-46; Trafvenfelt, Anmärkningar, 20.

51 Schouw, "Om naturhistorisk Underviisning”; Schweigaard, "Om Nødvendigheden." See also Riis-Larsen, Naturvidenskab og dannelse, 99-100; Bjørndal, Frå formaldaning, 62-68.

52 Hammar, "Conflict Among Geniuses," 723. Cf. Hamann, "Bildung," 50.

53 Eriksson, Botanikens historia, 177-78. On their subsequent decline in status, see Koerner, "Carl Linnaeus," 159-60.

54 Retzius, Tankar om natural-historiens nytta.

55 Trafvenfelt, Anmärkningar, 5-6.
} 
professor of theology at Uppsala University and one of the authorities the Anmärkningar repeatedly referenced, claimed in a response sent to the Education Committee in 1816 (later published in a series of newspaper articles) that as a moral compass natural history was second only to religion. ${ }^{56}$ Despite these efforts, however, the materialistic aims associated with the natural sciences proved difficult to wash away.

\section{Negotiating the Stigma of Materialism}

In the first half of the nineteenth century, the natural sciences were hard pressed to compete with humanities curricula in many European countries, as several historical accounts have shown. In his study of William Whewell, Richard Yeo found that no easy defense of the natural sciences existed in England during this period. ${ }^{57}$ At the same time in France, Françoise Waquet has shown that attempts to "secure a wider role for the sciences ... aroused impassioned opposition" and consequently failed..$^{58}$ Similarly, Andreas Daum has found that the natural sciences were on the defensive in the German school system for the entirety of the century..$^{59}$ And, in her study of the emergence of Naturwissenschaft as a prominent concept during the first half of the nineteenth century, Phillips showed that the use of adjectives such as "useful," deemed positive during the Enlightenment, had become a "particular object of scorn." ${ }^{60}$ Thus, as William Clark has claimed, before the middle of the nineteenth century "natural scientists had to defend their subjects not in the pragmatic, utilitarian terms of the Enlightenment," but with the values of Bildung instead. ${ }^{61}$ Scandinavia was part of this overall pattern. By the time the Anmärkningar appeared in 1818, the estimation of the term "practical knowledge" had changed from positive to negative. It was sometimes even considered pejorative, a fact that the Anmärkningar's authors did their best to circumnavigate, for instance, by claiming natural history was a theoretical subject that served only to prepare individuals for practical endeavors. ${ }^{62}$

As Lorraine Daston has demonstrated, the value attached to the study of nature during the Enlightenment was "simultaneously moral, aesthetic, and economic," encompassing a "compound of norms."63 In the first half of the nineteenth century, advocates of the natural sciences in Sweden sometimes tried to have their cake and eat it too by pointing to both the material and the moral aims of studying nature. In so doing, they fueled suspicions of materialism that stood in the way of viewing natural history as "classical" or "humanistic." One of the most influential Swedish intellectuals who worried about the emotionless, materialist character of natural history was the educator Carl Ulric Broocman, whose academic work in pedagogy provided much of the inspiration for the proposal to fuse natural history and classical education in the Anmärkningar. Broocman was an early advocate of including natural history in secondary education, although not on utilitarian grounds. He called the practical approach to natural history "technological" and felt it contributed to the materialism and egotism of the age. If natural history was pursued for material gain, he argued, one could hardly be surprised by the "the loud lamentations of the Humanists." 64

Broocman furnished a link between classicism and the study of nature that the group needed, and they quoted him at length in the Anmärkningar. He pointed to how nature had been considered holy in antiquity, captivated the hearts and minds of the "Greeks and Orientals," and permeated ancient writing, including the canonical works that now formed the basis of truly cultivating (i.e., classical) knowledge. This spiritual relation to nature had been the source of the preeminence of "the Ancients," and, for Broocman, herein lay the value of nature for self-cultivation and nurturing "true humanity," especially for those who did not have access to higher learning, such as women. There was no better preparation for classical studies than the "innocent" observation of nature and her inner workings. ${ }^{65}$ To safeguard the study of natural history, he urged that its practitioners view it as an "education in the humanities" (humanistisk undervisning). ${ }^{66}$ Broocman's ideas thus aligned readily with the ambitions of the group behind the Anmärkningar.

\footnotetext{
${ }^{56}$ Ödmann, "Till Kongl." For comparable arguments, see Arrhenius, "Om Natural-historien," 141-43. See also Kärnfelt, Mellan nytta och nöje, 128. For natural history as a means of self-improvement, see Spary, "'Nature' of Enlightenment," 295.

57 Yeo, Defining Science, 32.

${ }^{58}$ Waquet, Latin, 14.

${ }^{59}$ Daum, Wissenschaftspopularisierung, 44.

${ }^{60}$ Phillips, Acolytes, 100.

${ }^{61}$ Clark, Academic Charisma, 447

62 Trafvenfelt, Anmärkningar, 11-12, 25.

${ }_{63}$ Daston, "Attention," 119; Phillips, "Friends of Nature," 44-45.

${ }^{64}$ Broocman, "Ungdomens Undervisning," 5-6.

65 Ibid., 9.

${ }^{66}$ Ibid., 28.
} 


\section{The Triumph of the Humanities}

Embracing the ideals of classical humanism was not only about achieving balance in the secondary school curriculum, however. ${ }^{67}$ As Brian Ogilvie has shown for an earlier period, "the triumph of the humanist secondary school curriculum ... provided naturalists with a set of attitudes toward language and classical texts that would infuse natural history."68 In light of this, as Phillips has argued, it can be misleading to view the appropriation of concepts such as Bildung merely as a sign of the "cultural subordination to the hegemonic power of classics." ${ }^{69}$ The Swedish case bears Phillips' claim out. For example, when the botany professor Carl Adolph Agardh argued for the pedagogical value of the study of nature, he pointed to the fact that great natural scientists such as Newton, Cuvier, and Linnaeus had all been trained in the humanities and had attained the highest form of humanistic edification (humanistisk bildning). ${ }^{70}$ For Agardh, natural scientists were also humanists.

At the time, Swedish natural scientists did not form an insulated community governed by a separate scientific creed. On the contrary, they were part of the same social elite as scholars in the humanities. ${ }^{71}$ All moved in the same academic circles and all belonged to the classically educated bourgeoisie. Such was the case more generally in Europe during this period. For example, William Clark has argued that practitioners of the natural sciences in Germany acted on a "social-cultural stage" that had largely been built and shaped by humanists. ${ }^{72}$ From a Swedish standpoint, it is thus illustrative that when, between 1831 and 1847, Agardh, Berzelius, and Fries, three of Sweden's most prominent natural scientists, were inducted into the prestigious Swedish Academy, which was dedicated to Sweden's linguistic and literary advancement, all construed their election as recognition of the natural sciences' role as an instrument of humanistic self-cultivation. ${ }^{73}$ For example, Fries, in his inaugural speech, referred to nature as a "perpetual wellspring of edification (bildning). ${ }^{74}$ And even Berzelius, who was later viewed as a scientist par excellence and the harbinger of the revival of the natural sciences, framed his speech around the role of classical knowledge as the yardstick against which his own science had to be measured. Custom dictated that all newly elected academicians give a eulogy of the deceased member whose place they were taking. Berzelius, who lauded the prominent classical humanist Carl von Rosenstein, humbly recognized the hegemony of classical humanism and praised Rosenstein as the man behind the "excellent" School Ordinance of 1820, the outcome of the very reform that the group behind the Anmärkningar had attempted to thwart in 1818. Admitting defeat in this battle, he lamented the exclusion of the natural sciences from the school curriculum, hoping that one day they would be awarded an esteemed place among the forms of knowledge that society considered "classical." ${ }^{75}$

\section{In Pursuit of Bildung}

When delivering what was probably the most ardent defense of natural history as a tool for self-cultivation in 1842, Fries departed from Berzelius' blanket wish that the natural sciences would one day be counted as part of a classical education. ${ }^{76}$ For Fries, the possibility of its inclusion depended on how one viewed and approached the natural sciences in general. If materialistic forms of the natural sciences were seen as detrimental to humanistic self-cultivation, then the opposite approach to them should be considered valuable. "If humanistic is the same as that which is purely human, then no study can be more humanistic than the study of nature," he proclaimed..$^{77}$ Fries thought that the low standing of natural history in the current school system could be easily remedied by viewing it as a bridge between mathematics and philosophy. Each of these disciplines could then subsume parts of this field. The negative view of natural history, Fries reasoned, was the result of it being confused with other fields of natural science whose objects were more practical. ${ }^{78}$ Unlike disciplines such as astronomy, physics, and chemistry, natural history was part of an altogether different sphere of knowledge: that of the historical disciplines, which were tasked with understanding human life and action. It was, Fries claimed, precisely the historical nature of natural history

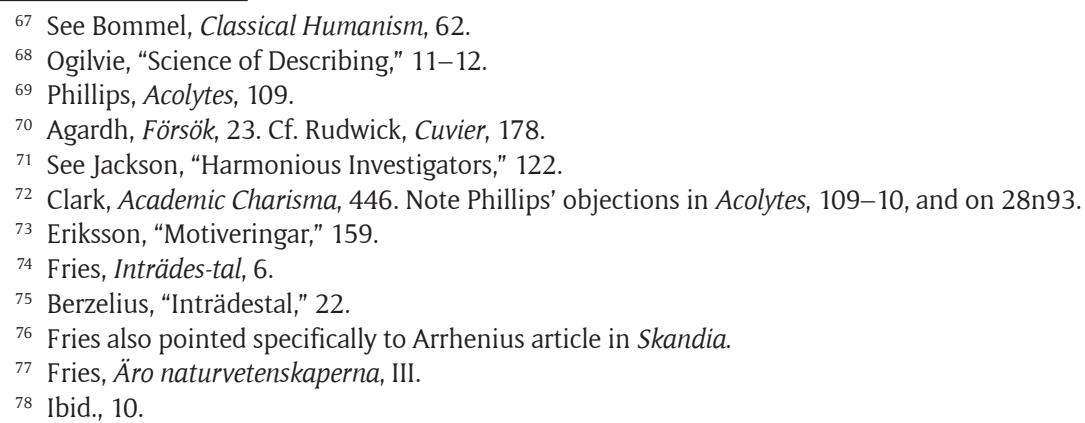


that made it suitable for self-cultivation. ${ }^{79}$ Specifically, natural history could train the student's judgment since even the simplest description of a plant demanded one's most intense attentiveness..$^{80}$ The same was true for the student's memory and powers of observation. At the same time, Fries was careful to make sure his claims would not be construed as a challenge to the humanities, emphasizing that no one wanted to diminish the study of classical languages. ${ }^{81}$ Instead, the fields should complement each other, as natural history without classical studies would be "dilettante-knowledge," nothing more than "a flower which blooms for only one day." 82

In 1850, Nils Johan Andersson, a botanist at Uppsala University, published a lecture that was arguably the swansong of the collective efforts to cast natural history in the garb of classical humanism. Citing Fries' pamphlet, Andersson expressed his frustration with the fact that despite so many eloquent defenses over the past decades (including the works mentioned in this article by Ödmann, Agardh, and Arrhenius), natural history was still viewed as materialistic and egotistic, its higher purposes ignored and its capacity to train the mind rejected..$^{83}$ Once more he emphasized the similarities between the natural sciences and the study of classical languages, the value of treating them as "allies," and the irrational fear of the former threatening the latter. ${ }^{84}$

Yet despite Andersson's frustrations, the hegemony of the humanities in secondary education had already begun to diminish. While echoes of the superiority of the humanities would continue to be heard for the rest of the century, the need to fit the natural sciences into the humanities-oriented curriculum ended in 1849 when the Parliament introduced a parallel program in secondary education. The program offered a science- and modern-language-based curriculum alongside the classical gymnasium track, which gave the natural sciences a designated place within secondary education. In another step towards affording the natural sciences an elevated status vis-á-vis the humanities, in 1850-1851 the Parliament passed a law that raised the salary level of natural history teachers to that of their classics colleagues. Significantly, proponents of the law had based their arguments on the value of the sciences for both self-cultivation and industry. ${ }^{85}$ Nevertheless, more than a decade later, in an opening address for the Scandinavian Association for the Advancement of Science, Fries still lamented that some continued to blame the natural sciences for undercutting "higher humanistic education." Even so, it was now possible for him to venture the prospect that they had in fact finally "penetrated" the humanities, thereby invigorating and advancing them. ${ }^{86}$

\section{Conclusion: A Humanities Regime}

During the first half of the nineteenth century, classical-humanist knowledge was firmly placed on top of the epistemological hierarchy in the Swedish higher education system. This meant that a knowledge regime strongly oriented towards the humanities dictated what forms of knowledge were considered valuable to society. As a result, it became necessary to model the natural sciences after certain attributes of humaniora. The Anmärkningar was an ambitious collective effort to include natural history in classical education, and although it was ignored by government officials, it provided inspiration for others who advocated for the natural sciences' inclusion in the secondary school curriculum and became part of the public debate on education for several decades. Without understanding the premises of these negotiations, we cannot hope to trace the oscillations in the perceived value of different forms of knowledge nor their place and standing in Sweden over time. Moreover, the case presented in this article demonstrates that forgotten or failed strategies in contests over the value of different forms of knowledge are key to understanding the historical development of knowledge regimes. ${ }^{87}$

The debate under scrutiny here revolved around the curriculum of Swedish gymnasia in the first half of the nineteenth century. Advocates for the natural sciences had the best chance of gaining entry to it by using natural history as a kind of crowbar, prying a first opening for other sciences. ${ }^{88}$ Natural history lent itself to this purpose because it was not as fixed or as sharply defined as other fields of natural science. This more

\footnotetext{
${ }^{79}$ Ibid., 9-10. See also Arrhenius, “Om Natural-historien,” 132. Cf. Ogilvie, “Natural History," 99.

${ }^{80}$ Cf. Daston, "Attention," 100-101.

${ }^{81}$ Fries, Äro naturvetenskaperna, 17-18.

82 Ibid., 26.

${ }^{83}$ Andersson, "Naturalhistoriens," 50.

84 Ibid., 39.

${ }^{85}$ Högvördiga preste-ståndets protokoll, 154. Eriksson, I andans kraft, 286. See also, Kärnfelt, Mellan nytta och nöje, 140-41.

${ }^{86}$ Fries, Botaniska utflygter, 3.

${ }^{87}$ See Mulsow, "History of Knowledge," 159; Lässig, "History of Knowledge," 45.

${ }^{88}$ Sometimes, however, geography, chemistry, and the natural sciences in general were also advanced as instruments of "humanistic self-cultivation." See Styffe, "Om den geografiska undervisningen"; Svanberg, Har kemin ej en plats.
} 
amorphous view of natural history corresponds with Staffan Müller-Wille's claim that it "never constituted a homogeneous and uniform knowledge regime, governed by a common paradigm or episteme." 89 In a similar vein, Emma Spary has pointed to the "eclectic quality" of natural history. ${ }^{90}$ This lack of definition made it relatively easy to endow the field with values and purposes that rendered it acceptable within a humanities regime. Another reason the group and their allies in this cause could argue-and believe in-the alignment between the natural sciences and the humanities was that they were to a large degree trained in the humanities themselves.

This article has addressed what in recent years has come to be seen as a lacuna or "missing link" in the history of science: the historical relation of the natural sciences to the humanities within an integrated history of knowledge. ${ }^{91}$ So far, neither the rise of the classical-humanist regime nor its subordination of the natural sciences has been widely appreciated by historians. ${ }^{92}$ Until recently, the habitual way of looking at the competing views of knowledge found during the first half of the nineteenth century has been to cast them in terms of the binary categories of the Enlightenment and Romanticism. ${ }^{93}$ While these large cultural categories undeniably played a role in the background, the specific relevance of the humanities-as a form of knowledge and inquiry-has rarely been brought into the equation. This has resulted in serious gaps in both the history of science and the history of the humanities, disciplines that have typically worked in isolation from each other. A truly integrated history of knowledge requires that we take another look at the dialectical processes at work between forms of knowledge that have traditionally, but all too stereotypically, been viewed as being at odds with one another.

\section{Acknowledgements}

The author would like to thank Anna Nilsson Hammar and Niklas Svensson for their helpful and insightful comments on earlier versions of the paper and Staffan Bergwik for inspiring discussions on structure and form.

\section{Competing Interests}

The author has no competing interests to declare.

\section{Bibliography}

Agardh, Carl Adolph. Försök till rättfärdigande af det nya skol-systemet. Stockholm, 1844.

Andersson, Nils Johan. "Naturalhistoriens vigt och behandling i elementarläroverket." Tidskrift för lärare och uppfostrare 2 (1850): 33-41, 65-73.

Anwisningar och råd till lärare, om sättet att werkställa hwad Kongl. Maj:t i nåder uti skolordningen af den 16 dec. 1820 stadgat och anbefallt: bihang till Uppfostrings-comiteens underdåniga förslag till skol-lag. Stockholm 1821.

Arrhenius, Johan Petter. "Om Natural-historien såsom undervisningsämne vid Sveriges gymnasier." Skandia 2, no. 9 (1837): 123-78.

Askeberg, Sven. Pedagogisk reformverksamhet: Ett bidrag till den svenska skolpolitikens historia, 1810-1825. Uppsala: Uppsala University, 1976.

Beckman, Jenny. "Collecting Standards: Teaching Botanical Skills in Sweden, 1850-1950." Science in Context 24, no. 2 (2011): 239-58. DOI: https://doi.org/10.1017/S0269889711000081

Beckman, Jenny. "Nature's Palace: Constructing the Swedish Museum of Natural History." History of Science 42 (2004): 85-111. DOI: https://doi.org/10.1177/007327530404200103

Bergius, Axel Theodor. "Är tiden inne, att åt naturvetenskaperna anvisa deras rätta plats inom skolan?" Tidskrift för lärare och uppfostrare 1 (1849): 76-84.

Berzelius, Jacob. "Inträdes-Tal af Friherre Jakob Berzelius." In Svenska akademiens handlingar ifrån år 1796, vol. 19, 6-25. Stockholm: Norstedt, 1841.

\footnotetext{
${ }^{89}$ Müller-Wille, "Names and Numbers," 114. Cf. Jardine and Spary, "Introduction," 3.

90 Spary, Utopia's Garden, 5-6.

${ }^{91}$ Bod, A New History, 7. See also Bod et al., "New Field," 6; Bod and Kursell, "Introduction," 338; Daston, "History of Science," 142-43. On the history of knowledge, see also Sarasin, "Was ist Wissensgeschichte?"; Burke, History of Knowledge?; Lässig, "History of Knowledge"; Östling et al., Circulation of Knowledge; and now the special issue (42) of Berichte zur Wissenschaftsgeschichte.

92 Cf. Ogilvie, Science of Describing, 10; Bommel, "'Bildung' and 'Wissenschaft,"' 4. See also Daston, "Comment," 174-75. Leonhardt, Latin, 266, 275; Bommel, Classical Humanisim, 12; Daum, "Science, Politics, and Religion," 114.

${ }_{93}$ See, e.g., Eriksson, Elias Fries. For a recent critique of a "stereotyped opposition" between the Enlightenment and Romanticism, see Gambarotto, "Lorenz Oken," 331. See also Livingstone, "Science," 72; Daston, "History of Science," 140-41.
} 
Berzelius, Jacob. Själfbiografiska anteckningar. Stockholm: Norstedt, 1901.

Bjørndal, Bjarne. "Frå formaldaning til allmenndaning: Eit studium av allmenndaningsomgrepet i norsk pedagogikk i det 19. hundreåret." PhD diss., University of Oslo, 1964.

Blair, Ann. "Disciplinary Distinctions before the 'Two Cultures."' The European Legacy 13, no. 5 (2008): 57788. DOI: https://doi.org/10.1080/10848770802268741

Bod, Rens. "A Comparative Framework for Studying the Histories of the Humanities and Science." Isis 106, no. 2 (2015): 367-77. DOI: https://doi.org/10.1086/681979

Bod, Rens. A New History of the Humanities: the Search for Principles and Patterns from Antiquity to the Present. Oxford: Oxford University Press, 2013. DOI: https://doi.org/10.1093/acprof: oso/9780199665211.001.0001

Bod, Rens. "Has There Ever Been a Divide? A Longue Durée Perspective." History of Humanities 3, no. 1 (2018): 15-25. DOI: https://doi.org/10.1086/696299

Bod, Rens, Jaap Maat, and Thijs Weststeijn. "Introduction: The Making of the Modern Humanities." In The Making of the Humanities. Vol. 3, The Modern Humanities, edited by Rens Bod, Jaap Maat and Thijs Weststeijn, 13-24. Amsterdam: Amsterdam University Press, 2014. DOI: https://doi.org/10.1515/97890 48518449-001

Bod, Rens, and Julia Kursell. "Introduction: The Humanities and the Sciences." Isis 106, no. 2 (2015): 337-40. DOI: https://doi.org/10.1086/681993

Bod, Rens, Julia Kursell, Jaap Maat and Thijs Weststeijn. "A New Field: History of Humanities." History of Humanities 1, no. 1 (2016): 1-8. DOI: https://doi.org/10.1086/685056

Bommel, Bas van. "Between 'Bildung' und 'Wissenschaft': The $19^{\text {th }}$-century German Ideal of Scientific Education." European History Online (EGO) (December 14, 2015). http://www.ieg-ego.eu/bommelb2015-en URN: urn:nbn:de:0159-2015120917.

Bommel, Bas van. Classical Humanism and the Challenge of Modernity: Debates on Classical Education in 19th-century Germany. Berlin: De Gruyter, 2015. DOI: https://doi.org/10.1515/9783110365931

Bouterse, Jeroen, and Bart Karstens. "A Diversity of Divisions: Tracing the History of the Demarcation between the Sciences and the Humanities." Isis 106, no 2 (2015): 341-52. DOI: https://doi.org/10. 1086/681995

Broocman, Carl Ulric. "Om Ungdomens Undervisning i Natural-Historien." Magasin för föräldrar och lärare 6 (1812): 1-31.

Burke, Peter. What is the History of Knowledge? Cambridge, UK: Polity Press, 2016.

Clark, William. Academic Charisma and the Origins of the Research University. Chicago: University of Chicago Press, 2008.

Cunningham, Andrew, and Perry Williams. "De-centering the 'Big Picture': 'The Origins of Modern Science' and the Modern Origins of Science." British Journal for the History of Science 26, no. 4 (1993): 407-32. DOI: https://doi.org/10.4324/9781351219549-3

Curry, Helen A., Nicholas Jardine, James A. Secord, and Emma C. Spary, eds. Worlds of Natural History. Cambridge, UK: Cambridge University Press, 2018. DOI: https://doi.org/10.1017/9781108225229

Daston, Lorraine. "Attention and the Values of Nature in the Enlightenment." In The Moral Authority of Nature, edited by Lorraine Daston and Fernando Vidal, 100-126. Chicago: University of Chicago Press, 2003. DOI: https://doi.org/10.7208/chicago/9780226136820.003.0005

Daston, Lorraine. "Comment" on Martin Mulsow, "History of Knowledge." In Debating New Approaches to History, edited Marek Tamm and Peter Burke, 173-78. London: Bloomsbury Academic, 2018.

Daston, Lorraine. "The History of Science and the History of Knowledge." KNOW: A Journal on the Formation of Knowledge 1, no. 1 (2017): 131-54. DOI: https://doi.org/10.1086/691678

Daum, Andreas, W. "Science, Politics, and Religion: Humboldtian Thinking and the Transformations of Civil Society in Germany, 1830-1870." Osiris 17 (2002): 107-40. DOI: https://doi.org/10.1086/649361

Daum, Andreas, W. Wissenschaftspopularisierung im 19. Jahrhundert:Bürgerliche Kultur, naturwissenschaftliche Bildung und die deutsche Öffentlichkeit, 1848-1914. Munich: Olderbourg, 2002. DOI: https://doi. org/10.1515/9783486832501

Eriksson, Gunnar. Botanikens historia i Sverige intill år 1800. Uppsala: Almqvist \& Wiksell, 1969.

Eriksson, Gunnar. Elias Fries och den romantiska biologien. Uppsala: Uppsala University, 1962.

Eriksson, Gunnar. "Motiveringar för naturvetenskap: En översikt av den svenska diskussionen från 1600-talet till första världskriget." Lychnos (1971/72): 121-70.

Eriksson, Nils. "I andans kraft, på sannings stråt-": de skandinaviska naturforskarmötena, 1839-1936." Göteborg: Acta Universitatis Gothoburgensis, 1991. 
Florin, Christina, and Ulla Johansson. "Där de härliga lagrarna gro-": Kultur, klass och kön i det svenska läroverket, 1850-1914. Stockholm: Tiden, 1993.

Fries, Elias. Äro naturvetenskaperna något bildnings-medel? Upsala: Leffler och Sebell, 1842.

Fries, Elias. Botaniska utflygter: En samling af strödda tillfällighetsskrifter. Vol. 3. Stockholm: Hæggström: 1864.

Fries, Elias. Inträdes-tal hållet i Svenska akademien [över E. G. Geijer] den 2 december 1847. Stockholm, 1849.

Fuchs, Eckhardt. "Nature and Bildung: Pedagogical Naturalism in Nineteenth-Century, Germany." In The Moral Authority of Nature, edited by Lorraine Daston and Fernando Vidal, 155-81. Chicago: University of Chicago Press, 2004. DOI: https://doi.org/10.7208/chicago/9780226136820.003.0007

Gambarotto, Andrea. "Lorenz Oken (1779-1851): Naturphilosophie and the reform of natural history." The British Journal for the History of Science 50, no. 2 (2017): 329-40. DOI: https://doi.org/10.1017/ S0007087417000310

Hamann, Julian. "'Bildung' in German human sciences: The discursive transformation of a concept." History of the Human Sciences 24, no. 5 (2011): 48-72. DOI: https://doi.org/10.1177/0952695111421865

Hamann, Julian. "Boundary Work between Two Cultures: Demarcating the Modern Geisteswissenschaften." History of Humanities 3, no. 1 (2018): 27-38. DOI: https://doi.org/10.1086/696300

Hamann, Julian. Die Bildung der Geisteswissenschaften: zur Genese einer sozialen Konstruktion zwischen Diskurs und Feld. Köln: Halem, 2014.

Hammar, Isak. "A Conflict among Geniuses: Challenges to the Classical Paradigm in Sweden, 1828-1832." History of Education 48, no. 6 (2019): 713-30. DOI: https://doi.org/10.1080/0046760X.2018.1543458

Hammar, Isak. "Conflict, Consensus and Circulation: The Public Debates on Education in Sweden, c. 1800-1830." In Circulation of Knowledge: Explorations in the History of Knowledge, edited by Johan Östling et al., 144-59. Lund: Nordic Academic Press, 2018.

Hjort, Peder. Tanker till nøiere Eftertanke om lard Underviisning og dens Formaal. Copenhagen, 1829.

Jackson, Myles W. "Harmonious Investigators of Nature: Music and the Persona of the German Naturforscher in the Nineteenth Century." Science in Context 16, no. 1/2 (2003): 121-45. DOI: https://doi.org/10.1017/ S0269889703000759

Jacob, Christian. "Lieux de savoir: Places and Spaces in the History of Knowledge." KNOW: A Journal on the Formation of Knowledge 1, no. 1 (2017): 85-102. DOI: https://doi.org/10.1086/692293

Jardine, Nicholas, and Emma Spary. "Introduction: the Natures of Cultural History." In Cultures of Natural History, edited by Nicholas Jardine et al., 3-13. Cambridge, UK: Cambridge University Press, 1996.

Jardine, Nicholas, James A. Secord, and Emma C. Spary, eds. Cultures of Natural History. Cambridge, UK: Cambridge University Press, 1996.

Johannisson, Karin. "Naturvetenskap på reträtt: en diskussion om naturvetenskapens status under svenskt 1700-tal." Lychnos (1979/80): 109-54.

Kärnfelt, Johan. Mellan nytta och nöje: ett bidrag till populärvetenskapens historia i Sverige. Eslöv: B. Östlings bokförl. Symposion, 2000.

Koerner, Lisbet. "Carl Linnaeus in his time and place." In Cultures of Natural History, edited by Nicholas Jardine et al., 145-62. Cambridge, UK: Cambridge University Press, 1996.

Krämer, Fabian. "Shifting Demarcations: an Introduction." History of Humanities 3, no. 1 (2018): 5-14. DOI: https://doi.org/10.1086/696298

Kutschmann, Werner. Naturwissenschaft und Bildung. Der Streit der "Zwei Kulturen." Stuttgart: Klett-Cotta, 1999.

Lässig, Simone. "The History of Knowledge and the Expansion of the Historical Research Agenda." Bulletin of the German Historical Institute 59 (2016): 29-58.

Leonhardt, Jürgen. Latin:Story of a World Language. Cambridge, MA: The Belknap Press of Harvard University Press, 2013. DOI: https://doi.org/10.4159/harvard.9780674726277

Liedman, Sven-Eric. "In Search of Isis: General Education in Germany and Sweden." In The European and American University since 1800, edited by Sheldon Rothblatt and Björn Wittrock, 74-106. Cambridge, UK: Cambridge University Press, 1993. DOI: https://doi.org/10.1017/CBO9780511720925.003

Liedman, Sven-Eric. "Utilitarianism and the Economy." In Science in Sweden: The Royal Swedish Academy of Sciences, 1739-1989, edited by Tore Frängsmyr, 23-44. Canton: Science History Publications, 1989.

Livingstone, David, N. "Science, Site and Speech: Scientific Knowledge and the Spaces of Rhetoric." History of the Human Sciences 20, no. 2 (2007): 71-98. DOI: https://doi.org/10.1177/0952695107076516

Löwegren, Yngve. Naturaliesamlingar och naturhistorisk undervisning vid läroverken. Stockholm: Föreningen för svensk undervisningshistoria, 1974. 
Müller-Wille, Staffan. "Names and Numbers: 'Data' in Classical Natural History, 1758-1859." Osiris 32, no. 1 (2017): 109-28. DOI: https://doi.org/10.1086/693560

Mulsow, Martin. "History of Knowledge." In Debating New Approaches to History, edited by Marek Tamm and Peter Burke, 159-73. London and New York: Bloomsbury 2018.

Nilehn, Lars H. Nyhumanism och medborgarfostran: åsikter om läroverkets målsättning, 1820-1880. Lund: Gleerup, 1975.

Ödmann, Samuel. “Till Kongl. Uppfostrings-komittén, Ödmjukaste Memorial." Allmänna Journalen 196-197 (1816).

Ogilvie, Brian W. "Natural History, Ethics, and Physico-theology." In Historia: Empiricism and Erudition in Early Modern Europe, edited by Gianna Pomata and Nancy G. Siraisi, 75-103. Boston: MIT Press, 2005.

Ogilvie, Brian W. The Science of Describing: Natural History in Renaissance Europe. Chicago: University of Chicago Press, 2006. DOI: https://doi.org/10.7208/chicago/9780226620862.001.0001

Ørsted to Berzelius March 23 ${ }^{\text {rd }}$, 1835. In Correspondence de H.C. Ørsted avec divers savants, edited by M.C. Harding. Copenhagen: Aschehoug, 1920.

Ørsted, Hans Christian. "Naturvidenskaben, betragtet som en af Grundbestanddelene i Menneskets Dannelse." Reprinted in Laurits Lauritsen. Hans Christian Ørsted: et blad af fysikens og kemins historie. Copenhagen: Andr. Fred. Høst \& Søns Forlag, 1909, 123-32.

Ørsted, Hans Christian. "Om den dannende Virkning, Naturvidenskabens Anvendelse maa udøve." In Samlede og efterladte skrifter, vol. 2, 66-80. Copenhagen, 1851.

Ortolano, Guy. The Two Cultures Controversy: Science, Literature and Cultural Politics in Postwar Britain. Cambridge, UK: Cambridge University Press, 2009.

Östling, Johan, Erling Sandmo, David Larsson Heidenblad, Anna Nilsson Hammar, Kari H. Nordberg. Circulation of Knowledge: Explorations in the History of Knowledge. Lund, SE: Nordic Academic Press, 2018.

Phillips, Denise. Acolytes of Nature: Defining Natural Science in Germany, 1770-1850. Chicago: University of Chicago Press, 2012. DOI: https://doi.org/10.7208/chicago/9780226667393.001.0001

Phillips, Denise. "Friends of Nature: Urban Sociability and Regional Natural History in Dresden, 1800-1850." Osiris 18, no. 1 (2003): 43-59. DOI: https://doi.org/10.1086/649376

Protocoll, hållna hos högloflige ridderskapet och adeln, vid lagtima riksdagen i Stockholm, vol. 4, 21 May, 356-360.

Retzius, Anders Jahan. Tankar om natural-historiens nytta och värde. Lund University, 1811.

Rheinberger, Hans-Jörg. "Culture and Nature in the Prism of Knowledge." History of Humanities 1, no. 1 (2016): 155-81. DOI: https://doi.org/10.1086/685064

Riis Larsen, Børge. Naturvidenskab og dannelse: studier i fysik- og kemiundervisningens historie i den højere skole indtil midten af 1800-tallet. Espergærde: Dansk Selskab for historisk Kemi, 1991.

Rudwick, Martin J. S. Georges Cuvier, Fossil Bones, and Geological Catastrophes: New Translations and Interpretations of the Primary Texts. Chicago and London: University of Chicago Press, 1998. DOI: https:// doi.org/10.7208/chicago/9780226731087.001.0001

Sarasin, Philipp. "Was ist Wissensgeschichte?" Internationales Archiv für Sozialgeschichte der Deutschen Literatur 36, no. 1 (2011): 159-72. DOI: https://doi.org/10.1515/iasl.2011.010

Saxtorph, Jacob. Forsog til en Lerebog i Naturlceren ved den forste systematiske Underviisning i Skolerne. Copenhagen: Gyldendals, 1799.

Schouw, Joakim Frederik. "Om naturhistorisk Underviisning i de lærde Skoler." Dansk ugeskrift 2 (1832): $141-53$.

Schweigaard, Anton Martin. "Om Nødvendigheden af at indskrænke Sprogstudiets Omfang i den lærde Undervisning." Vidar (1832): 1-5, 9-12.

Segerstedt, Torgny T. Den akademiska friheten, 1809-1832. Uppsala: Acta Universitatis Upsaliensis, 1976.

Siljeström, Per Adam. "Om naturvetenskapernas studium vid elementar-läroverken." Tidskrift för lärare och uppfostrare 2 (1847-1848).

Siraisi, Nancy G. History, Medicine and the Traditions of Renaissance Learning. Ann Arbor: University of Michigan Press, 2007. DOI: https://doi.org/10.3998/mpub.243426

Snow, Charles Percy. The Two Cultures. Cambridge, UK: Cambridge University Press, 1993.

Spary, Emma C. "The 'Nature' of Enlightenment." In The Sciences in Enlightened Europe, edited by William Clark, Jan Golinski, and Simon Schaffer, 272-304. Chicago and London: The University of Chicago Press, 1999. 
Spary, Emma C. Utopia's Garden: French Natural History from Old Regime to Revolution. Chicago: University of Chicago Press, 2000. DOI: https://doi.org/10.7208/chicago/9780226768700.001.0001

Stray, Christopher. Classics Transformed: Schools, Universities, and Society in England, 1830-1960. Oxford: Clarendon, 1998.

Styffe, Carl Gustaf. "Om den geografiska undervisningen och dess förhållande till den naturvetenskapliga och historiska i allmänhet." Frey 7 (1850): 386-400.

Svanberg, Lars. Har kemin ej en plats uti allmänna bildningen?: Ett föredrag. Stockholm: Bonnier, 1847.

Torstendahl, Rolf. "The Transformation of Professional Education in the Nineteenth Century." In The European and American University since 1800, edited by Sheldon Rothblatt and Björn Wittrock, 109-41. Cambridge, UK: Cambridge University Press, 1993. DOI: https://doi.org/10.1017/CBO9780 511720925.004

Trafvenfelt, Eric Carl. Anmärkningar om natural-historiens lärande vid rikets lägre läroverk, $i$ anledning af kongl. uppfostrings-kommitténs underdåniga förslag till en förbättrad skol-ordning. Stockholm, 1818.

Veit-Brause, Irmline. "Scientists and the Cultural Politics of Academic Disciplines in Late 19th-Century Germany: Emil Du Bois-Reymond and the Controversy over the Role of the Cultural Sciences." History of the Human Sciences 14, no. 4 (2001): 31-56. DOI: https://doi.org/10.1177/095269510101400402

Waquet, Françoise. Latin, or, The Empire of a Sign: from the Sixteenth to the Twentieth Centuries. London: Verso, 2001.

Wennås, Olof. Striden om latinväldet: idéer och intressen $i$ svensk skolpolitik under 1800-talet. Stockholm: Almqvist \& Wiksell, 1966.

Yeo, Richard R. Defining Science: William Whewell, Natural Knowledge and Public Debate in Early Victorian Britain. Cambridge, UK: Cambridge University Press, 1993. DOI: https://doi.org/10.1017/CBO9780 511521515

How to cite this article: Hammar, Isak. "Classical Nature: Natural History, Classical Humanism, and the Value of Knowledge in Sweden, 1800-1850." Journal for the History of Knowledge 2, no. 1 (2021): 1, pp. 1-14. DOI: https:// doi.org/10.5334/jhk.2

Submitted: 04 June 2019

Accepted: 26 March 2020

Published: 25 February 2021

Copyright: (c) 2021 The Author(s). This is an open-access article distributed under the terms of the Creative Commons Attribution 4.0 International License (CC-BY 4.0), which permits unrestricted use, distribution, and reproduction in any medium, provided the original author and source are credited. See http://creativecommons.org/licenses/by/4.0/.

] $\mathbf{u}[\quad J$ Journal for the History of Knowledge is a peer-reviewed open access journal published by Ubiquity Press. 